\title{
Potential for nitrate leaching from different land uses in the Pukekohe area
}

\author{
J.R. CRUSH ${ }^{1}$, S.N. CATHCART ${ }^{2}$, P. SINGLETON ${ }^{1}$ and R.D. LONGHURST ${ }^{1}$ \\ ${ }^{1}$ AgResearch, Ruakura Research Centre, Private Bag 3123, Hamilton \\ ${ }^{2}$ Auckland Regional Council, Private Bag 68-912, Auckland
}

\begin{abstract}
Nitrogen balances (inputs minus outputs) were calculated for 5 dairy farms, 5 orchards and a range of crops. All the balances were positive, i.e., surplus $\mathrm{N}$ was present and a proportion of this $\mathrm{N}$ will eventually reach the groundwater as nitrate. On a per ha basis, the greatest $\mathrm{N}$ surplus was from early potatoes $>$ winter cabbage, winter lettuce and squash $>$ dairying, kiwifruit, summer cabbage and summer lettuce $>$ pumpkins, onions and main crop potatoes $>$ dry stock farming. The area in each activity was multiplied by the surplus $\mathrm{N}$ factor to obtain the potential contribution of $\mathrm{N}$ to groundwater in the Pukekohe area. Early potatoes (217 $\mathrm{t} \mathrm{N})$, contribute much more than onions $(105 \mathrm{t} \mathrm{N})$, dairying $(59 \mathrm{t} \mathrm{N})$ or dry stock farming $(57 \mathrm{t} \mathrm{N})$. Other activities contributed $<30 \mathrm{t} \mathrm{N}$ each. Winter crops had higher surplus $\mathrm{N}$ levels than the same crop grown in summer because winter crops had higher fertiliser $\mathrm{N}$ inputs and lower crop off-take of N. Management practices contributing to the $\mathrm{N}$ surpluses include high rates of $\mathrm{N}$ fertiliser used on some crops; a long history of cultivation, which has reduced soil organic matter contents and the ability of these soils to immobilise mineral $\mathrm{N}$; and nil to intermittent use of cover crops to retain $\mathrm{N}$ in the topsoil.
\end{abstract}

Keywords: aquifers, dairying, fertiliser, groundwater, land use, management, nitrate, nitrogen balance, nitrate leaching, vegetables.

\section{Introduction}

Hickey Spring, the water supply source for Pukekohe township, and many rural domestic bores in the area, have nitrate concentrations that often exceed acceptable levels for potable water (Cathcart 1996). Elevated groundwater nitrate is not a new problem at Pukekohe Kingsford (1973) reported that nitrate-nitrogen in the Pukekohe public water supply was $9.0 \mathrm{ppm}$, almost twice as high as the second most contaminated supply in a survey of 114 supplies.

The catchment for the upper volcanic aquifer at Pukekohe covers about $50 \mathrm{~km}^{2}$ of the Pukekohe volcanic plateau. Current land uses are vegetable growing (50\% of the area), pasture (48\%), and orchards $(2 \%)$. The soils and climate are suited to intensive agriculture and vegetable growing has been important since last century.

Land management practices were surveyed to identify those that are major potential contributors of nitrate to the upper volcanic aquifer. A nitrogen balance ( $\mathrm{N}$ inputs minus $\mathrm{N}$ outputs) was calculated for each activity.

\section{Methods}

The survey area was bounded by the $60 \mathrm{~m}$ contour because springs discharging from the Upper Volcanic aquifer are located at approximately $60 \mathrm{~m}$ a.s.l. Five dairy farms, 5 orchards and 15 market gardens were surveyed in autumn 1996. To obtain the information required to calculate $\mathrm{N}$ balances, questionnaires were designed and the manager of each property was interviewed. Supplementary data were taken from publications. The $\mathrm{N}$ balance for drystock farming and $\mathrm{N}$ inputs from sewage were estimated from published New Zealand data.

General procedures followed Legg \& Meisinger (1982) and Hauck \& Tanji (1982) and detailed methods are in Crush et al. (1997).

$\mathrm{N}$ concentrations in crops were from Visser et al. (1990) and $\mathrm{N}$ inputs in irrigation water were calculated from the volume applied $\times \mathrm{N}$ concentration. $\mathrm{N}$ inputs in rain were ignored because they are likely to be $<3$ $\mathrm{kg} \mathrm{N} / \mathrm{ha} /$ year (Miller 1961) and uniform over this restricted area. $\mathrm{N}$ fixation by free-living soil microorganisms was omitted for similar reasons. Soil chemistry (Soil Fertility Service tests), subsoil nitrate contents (50-100 cm depth, extractable in $2 \mathrm{~N} \mathrm{KCl}$ ), topsoil hydraulic conductivities, soil physical structure, and use of cover crops were recorded on each property. $\mathrm{N}$ released during cultivation was calculated from Gradwell \& Arlidge's (1971) Pukekohe data on change in soil carbon with time under cultivation.

\section{Results}

$\mathrm{N}$ balances are summarised in Table 1 . The dairying and orcharding values are annual figures whereas the others are for an individual crop. All the activities had 
positive $\mathrm{N}$ balances, i.e., $\mathrm{N}$ surplus to the requirements for growth. Winter crops of potatoes, lettuce and cabbage had larger $\mathrm{N}$ surpluses than the same crops grown in summer.

The potential contribution of different land uses to groundwater nitrate were estimated from the area in each activity $x$ the surplus $N$ value. Results are summarised in Table 2 . Early potato growing contributed twice as much surplus $\mathrm{N}$ as onion growing, dairying and drystock farming producing about half the surplus $\mathrm{N}$ of onion growing. The contribution from pastures is an annual value and for a cropping property annual surplus $\mathrm{N}$ will depend on the sequence of crops grown.

Soil tests showed high nutrient status on all the properties, e.g., Olsen $P$ test values of 17-52 for dairy farms, 23-105 for orchards and 88-284 for vegetable growing properties. The dairy farms had on average $74 \mathrm{~kg}$ of nitrate-N/ha in the $30-100 \mathrm{~cm}$ subsoil, compared with $55 \mathrm{~kg}$ nitrate- $\mathrm{N}$ for orchards and $197 \mathrm{~kg}$ nitrate-N for cropping properties. Topsoil structure was generally good, with high saturated conductivities suggesting rapid infiltration of water.

Dairy farms and orchards had little bare ground. Some vegetable growing areas were kept fallow between crops, and others were bare for extended periods after cultivation and before planting. Cover crops were used regularly on some properties, but intermittently or not at all on others.

\section{Discussion}

Vegetable crops are fertilised for yields that may not be achieved. In contrast, the largest $\mathrm{N}$ input into dairy pastures - clover $\mathrm{N}$ fixation - is self-regulating, i.e., if growing conditions are poor, clovers fix less $\mathrm{N}$. The $\mathrm{N}$ balances from dairy farms are therefore comparatively well buffered against variation driven by changes in growing conditions. In the orchards, $\mathrm{N}$ storage in plants and the capacity of orchard soils to immobilise $\mathrm{N}$ also provide buffering against variable uptake and $\mathrm{N}$ use for growth. These factors mean that vegetable growing is always going to carry a high risk of generating surplus $\mathrm{N}$.
Table 1 Summary of the nitrogen balance data for different land uses (dairying and orcharding values are annual figure, others are for an individual crop).

-- $\mathrm{kg}$ surplus $\mathrm{N} / \mathrm{ha}$--

\begin{tabular}{rcrrc} 
No. & Mean N input & Mean N output & Mean & Range \\
\hline 5 & 241 & 84 & 157 & $142-178$ \\
8 & 543 & 115 & 429 & $282-587$ \\
8 & 268 & 176 & 92 & $29-181$ \\
14 & 241 & 123 & 118 & $17-230$ \\
4 & 337 & 171 & 166 & $124-211$ \\
1 & 116 & 90 & 26 & \\
3 & 430 & 144 & 286 & $245-359$ \\
3 & 370 & 184 & 186 & $161-211$ \\
3 & 326 & 88 & 238 & $123-401$ \\
1 & 249 & 81 & 168 & \\
1 & 301 & 59 & 242 & \\
1 & 212 & 92 & 120 & \\
\hline
\end{tabular}

Table 2 Potential contribution to groundwater nitrate of different land use activities around Pukekohe.

\begin{tabular}{lrrrrr}
\hline Activity & \multicolumn{2}{c}{$\begin{array}{c}\text { Nominal area (ha) } \\
\text { and \% of total area }\end{array}$} & $\begin{array}{c}\text { Surplus N } \\
\text { (kg/ha) }\end{array}$ & $\begin{array}{r}\text { Potentially leachable N } \\
\text { (tonnes) and\% of total N }\end{array}$ \\
\hline Dairying & 377 & 8.2 & 157 & 59 & 9.6 \\
Dry stock farming & 1884 & 40.9 & 30 & 57 & 9.3 \\
Kiwifruit & 133 & 2.8 & 166 & 22 & 3.5 \\
Onions & 892 & 19.4 & 118 & 105 & 17.1 \\
Main crop potatoes & 338 & 7.3 & 92 & 31 & 5.0 \\
Early potatoes & 506 & 11.0 & 429 & 217 & 35.4 \\
Winter cabbage & 94 & 2.0 & 242 & 20 & 3.2 \\
Summer cabbage & 94 & 2.0 & 168 & 16 & 2.6 \\
Winter lettuce & 35 & 0.7 & 286 & 10 & 1.6 \\
Summer lettuce & 35 & 0.7 & 186 & 7 & 1.1 \\
Squash & 105 & 2.2 & 238 & 25 & 4.0 \\
Pumpkin & 105 & 2.2 & 120 & 13 & 2.1 \\
Sewage & & & & 30 & 4.9 \\
Totals & $\mathbf{4 5 9 8}$ & & $\mathbf{6 1 2}$ & & \\
\hline
\end{tabular}

Within the market garden crops there was generally a positive relationship between the quantity of fertiliser $\mathrm{N}$ applied and the estimated surplus $\mathrm{N}$. For winter crops of potatoes, lettuce and cabbage, higher rates of $\mathrm{N}$ fertiliser and lower rates of $\mathrm{N}$ removal in crops generated larger $\mathrm{N}$ surpluses than occurred in summer crops. There were no consistent relationships between fertiliser $\mathrm{N}$ input and $\mathrm{N}$ removed in crops. However, sufficient variation was evident in the relationship between inputs and outputs to suggest that improved efficiency in $\mathrm{N}$ fertiliser use is a realistic goal.

The leading contributor of potentially leachable $\mathrm{N}$ within the survey area was early potatoes, followed by onions. Early potatoes combine a very high surplus $\mathrm{N}$ factor with extensive areas in crop, while onions have a large land area factor. Dairying combines one of the larger land areas with a surplus $\mathrm{N}$ factor similar to many 
of the summer crops, and drystock farming occupies the largest area. Conversion of drystock farming land to market gardens will significantly increase the potential for generation of surplus $\mathrm{N}$, through the effect of cultivation on mineralisation of soil organic $\mathrm{N}$ (Lloyd 1992), as well as the impact of changing to high surplus $\mathrm{N}$ generating systems. Conversely, regrassing of cropped land would reduce nitrate leaching until soil organic matter levels reached the equilibrium content for the soil type. Changing from dairying to onions or main crop potatoes would have a net long-term beneficial effect on the area's $\mathrm{N}$ balance - provided the impact of cultivation on soil organic $\mathrm{N}$ was managed carefully.

The rapid topsoil hydraulic conductivities indicate that nutrients are able to percolate down through the topsoil with water, rather than being lost in surface runoff. Most of the properties sampled showed high levels of plant-available nutrients, so nutrient supply should not be limiting for $\mathrm{N}$ uptake efficiency. The lowered organic matter content of many of the cropped soils probably exacerbates nitrate leaching, because little mineral $\mathrm{N}$ would be immobilised in the soil. In the orchard soils, and to a lesser extent in the pasture soils, there is probably enough carbon entering the soil (in prunings and dead plant litter with a wide $\mathrm{C}: \mathrm{N}$ ratio) to immobilise a substantial amount of mineral $\mathrm{N}$.

The only really significant input of $\mathrm{N}$ in irrigation water occurred in kiwifruit orchards where the combination of high total water application and abstraction from the surface aquifer meant that up to an additional $50 \mathrm{~kg}$ $\mathrm{N} / \mathrm{ha}$ was applied. This input should be discounted from the $\mathrm{N}$ fertiliser rate when it is calculated. On soils cultivated for $>40$ years, there is not likely to be much $\mathrm{N}$ released from soil organic matter because only very recalcitrant organic matter will still be present. On younger sites, agronomically significant quantities of $\mathrm{N}$ may be mineralised during cultivation. Guidelines are required for an approximation of $\mathrm{N}$ release during cultivation that will allow some tuning of $\mathrm{N}$ fertiliser inputs. An alternative approach would be use of soil mineralisation tests. Crop residues were included as an input into the crop $\mathrm{N}$ balances because of their role as a potential $\mathrm{N}$ input to subsequent crops. Most crop residues were ploughed in. For potatoes this represents about $20 \%$ of the $\mathrm{N}$ taken up by the crop (Greenwood et al. 1985), or 20-30 kg N/ha. For onions, plant residues provide an insignificant $\mathrm{N}$ input to the soil, whereas for a summer lettuce crop, residue $\mathrm{N}$ may reach $100 \mathrm{~kg}$ $\mathrm{N} / \mathrm{ha}$. For a following crop, the $\mathrm{N}$ fertiliser rate should be adjusted to allow for residue $\mathrm{N}$ or if planting is delayed, a cover crop could be used to retain $\mathrm{N}$ in the topsoil.

Only four growers did not use cover crops, but it was evident that many growers used cover cropping sporadically. Cover cropping is an old, proven technology, with many examples of its value in retaining $\mathrm{N}$ in the topsoil and reducing nitrate leaching (Meisinger et al. 1991). Requirement for Pukekohe growers should include development of management packages that include routine use of cover crops, and simple adjustments to fertiliser inputs for subsequent crops. Cover cropping imposes additional costs on growers, and these costs are unlikely to be recovered from relatively small reductions in $\mathrm{N}$ fertiliser use. However, the development of environmentally friendly growing systems that would allow vegetables to be grown and marketed under an "eco-label" may provide the financial returns necessary to stimulate the adoption of new practices.

The practice of growing winter crops with high $\mathrm{N}$ fertiliser inputs is not sustainable environmentally and may very well contradict provisions of the Resource Management Act. A major reduction in use of conventional fertiliser could reduce crop yields unless fertiliser placement and timing were improved to compensate. The annual and longer term $\mathrm{N}$ balance for vegetable growing as a land use option will depend very strongly on the sequence of crops grown. Rather than focusing on the $\mathrm{N}$ balance of individual crops, it might be better to take a longer term target $\mathrm{N}$ balance. This would give growers considerable flexibility to manage $\mathrm{N}$ outputs by choice of crop rotations. Given the natural advantages that Pukekohe has for vegetable growing, the best option is a strenuous effort to develop crop husbandry practices that reduce surplus $\mathrm{N}$ production. These could include closer matching of the size and timing of fertiliser inputs to crop nutrient requirements, making crop residue $\mathrm{N}$ part of the $\mathrm{N}$ budget for the next crop, use of controlled-release fertilisers, raising the organic matter content of cropping soils, and cover cropping.

If new growing systems that protect the groundwater are developed at Pukekohe, and these involve an increase in production costs, then clearly these additional costs will have to be passed on to processors and eventually the consumers. The society at large has to decide the long-term value of clean groundwater and be prepared to meet the cost of its maintenance. Within such a framework there is plenty of scope for growers, researchers and the related agribusinesses to work together and improve the current cropping methods.

\section{ACKNOWLEDGEMENTS}

Farmers and growers for their co-operation; Brett Kerrisk (BOP Fertiliser Ltd.), Bob O'Reilly (LIC), Richard Wood (Vegcon Services), G. Hunter (Pukekohe Vegetable Growers Association), S. Pilcher (Counties Kiwifruit Growers Association) for information and 
advice; Matthew Mills, Brett Addison, Mark Boyes and Li Ouyang of AgResearch for technical support. This work was jointly funded by the Auckland Regional Council, New Zealand Fertiliser Manufacturers' Research Association and NZ Vegetable and Potato Growers Federation.

\section{REFERENCES}

Cathcart, S.N. 1996. An investigation of the nitrate contamination of an unconfined, shallow, fractured, basaltic aquifer at Pukekohe, South Auckland, New Zealand. Unpublished MSc thesis, Auckland University.

Crush, J.R.; Singleton, P.; Longhurst, R.D. 1997. Nitrogen balances for different uses of land in the Pukekohe area, South Auckland. AgResearch report to Auckland Regional Council, 45 pp.

Gradwell, M.W.; Arlidge, E.Z. 1971. Deterioration of soil structure in the market gardens of the Pukekohe district, New Zealand. New Zealand journal of agricultural research 14: 288-306.

Greenwood, D.J.; Neeteson, J.J.; Draycott, A. 1985. Response of potatoes to $\mathrm{N}$ fertiliser: quantitative relations for components of growth. Plant and soil 85: 163-183.
Hauck, R.D.; Tanji, K.K. 1982. Nitrogen transfers and mass balances. In: Nitrogen in agricultural soils. Ed: Stevenson, F.J., Agronomy No. 22: 891-925.

Kingsford, M. 1973. The chemistry of New Zealand drinking water supplies. Chemistry Division report No. CD 2161, New Zealand Department of Scientific and Industrial Research, $56 \mathrm{pp}$.

Legg, J.O.; Meisinger, J.J. 1982. Soil nitrogen budgets. In: Nitrogen in agricultural soils. Ed: Stevenson, F.J., Agronomy No. 22: 503-566.

Lloyd, A. 1992. Nitrate leaching under arable land ploughed out from grass. The Fertiliser Society Proceedings No. 330: 3-31.

Meisinger, J.J.; Hargrove, W.L.; Mikkelsen, R.L.; Williams, J.R.; Benson, V.W. 1991. Effects of cover crops on groundwater quality. pp. 57-68, In: Cover crops for clean water. Ed.W.L. Hargrove. Ankeny, Iowa, Soil and Water Conservation Society.

Miller, R.B. 1961. The chemical composition of rainwater at Taita, New Zealand. New Zealand journal of science 4: 844-853.

Visser, F.R.; Hannah, D.J.; Bailey, R.W. 1990. Composition of New Zealand foods. 2. Export fruits and vegetables. Royal Society of New Zealand, Miscellaneous Series 20. 